\title{
Silicon Effects on Poa pratensis Responses to Salinity
}

\author{
Qi Chai
}

Key Laboratory of Grassland Agro-Ecosystem Ministry of Agriculture, College of Pastoral Agricultural Science and Technology, Lanzhou University, Lanzhou, 730020, The People's Republic of China

\author{
Xinqing Shao ${ }^{1}$ \\ Institute of Grassland Science, Animal and Technology College, China \\ Agricultural University, Beijing, 100193, The People's Republic of China
}

\section{Jianquan Zhang}

Key Laboratory of Grassland Agro-Ecosystem Ministry of Agriculture, College of Pastoral Agricultural Science and Technology, Lanzhou University, Lanzhou, 730020, The People's Republic of China

Additional index words. kentucky bluegrass, salt, silicon, salinity damage

\begin{abstract}
Understanding turfgrass response to silicon (Si) application under salinity conditions is important to find a way to improve turfgrass salt tolerance for turf management. The objective of the study was to investigate effects of increasing amendment concentrations of $\mathrm{Na}_{2} \mathrm{SiO}_{3}$ on turf growth and distribution of $\mathrm{Na}^{+}$and $\mathrm{K}^{+}$in seedlings of kentucky bluegrass (KBG) (Poa pratensis L.) under salinity stress. This growth chamber experiment was consisted of a control (no salinity and no $\mathrm{Si}$ ) and five $\mathrm{Si}$ amendment treatments $\left(0,0.24,0.48,0.72\right.$, and $0.96 \mathrm{~g} \mathrm{Si} / \mathrm{kg}$ saline soil) under $10 \mathrm{~g} \cdot \mathrm{kg}^{-1}$ salinity conditions. Seed germination rate was significantly increased after $12 \mathrm{~d}$ under $0.48 \mathrm{~g} \cdot \mathrm{kg}^{-1}$ Si treatment. Plant height and canopy coverage were increased under $0.72 \mathrm{~g} \cdot \mathrm{kg}^{-1}$ Si treatment after 40 and $44 \mathrm{~d}$ of treatment, respectively, and tiller number was increased under $0.96 \mathrm{~g} \cdot \mathrm{kg}^{-1} \mathrm{Si}$ treatment compared with $\mathrm{O} \mathrm{Si}$ under saline conditions. With the supplement of $\mathrm{Si}$ at 0.48 to $0.96 \mathrm{~g} \cdot \mathrm{kg}^{-1}$, the ratio of $\mathrm{Na}^{+} / \mathrm{K}^{+}$in shoots was decreased and individual leaf area was increased compared with $\mathrm{O} \mathrm{Si}$ under saline conditions. The increase in individual leaf area was mainly the result of the increase in the leaf blade length. The concentration of $\mathrm{K}^{+}$in shoots was significantly increased, whereas the concentrations of $\mathrm{Na}^{+}$in roots were significantly decreased under all $\mathrm{Si}$ amendment treatments. The content of $\mathrm{K}^{+}$was higher in shoots than in roots, but the ratio of $\mathrm{Na}^{+} / \mathrm{K}^{+}$ in roots was higher than in shoots in all $\mathrm{Si}$ amendment treatments. The results indicate that under saline conditions, $\mathrm{Si}$ induced the transfer of $\mathrm{K}^{+}$from roots to shoots but inhibited the absorption and transfer of $\mathrm{Na}^{+}$, which may contribute to better turf quality and growth with Si treatment under saline conditions.
\end{abstract}

Salinity has been recognized as a major factor limiting crop productivity in many areas of the arid regions of the world where soil salt content is naturally high and precipitation is insufficient for leaching (Chinnusamy et al., 2005; Flowers, 2004; Matoh et al., 1988). In particular, turfgrass species are increasingly grown on soils plagued by accelerated urban development where salinity problems may develop from the use of saline irrigation water (Qian et al., 2001). KBG is

Received for publication 23 June 2010. Accepted for publication 19 Oct. 2010.

This work was supported by the program of D08060500460803 funded by Beijing Municipal Science \& Technology Commission. It was also supported by the 2004 and 2005 Opening Foundation of Key Laboratory of Grassland Agro-ecosystem Ministry of Agriculture.

We thank Dr. Bingru Huang, Emily Merewitz, and Zhenggang Guo for critical review of the manuscript. ${ }^{1}$ To whom reprint requests should be addressed; e-mail shaoxinqing@163.com. medium (Epstein, 1994; Winslow, 1992). Previous studies have shown that supplementing the soil with Si can improve salt tolerance of barley (Hordeum vulgare L.) (Liang, 1999; Liang et al., 1999), maize (Zea mays L.) (Shu and Liu, 2001), rice (Oryza sativa L.) (Kraska and Breitenbeck, 2010; Yeo et al., 1999), and wheat (Triticum aestivum L.) (Ahmad et al., 1992). However, limited research has investigated effects of Si supplement on salt tolerance of turfgrasses. Evaluating the effects of Si supplement on turfgrass salt stress tolerance may further our understanding of the role of $\mathrm{Si}$ in alleviating salt stress damage. Therefore, the objective of this study was to investigate effects of $\mathrm{Si}$ on turfgrass growth and distribution of $\mathrm{K}^{+}$and $\mathrm{Na}^{+}$in shoots and roots for $\mathrm{KBG}$ grown in saline soils.

\section{Materials and Methods}

Plant materials and growth conditions. 'Baron' KBG plants were grown at a seeding rate of one pure live seed $/ \mathrm{cm}^{2}$ in optimum environment in polyvinyl chloride (PVC) pots $(20 \mathrm{~cm}$ in diameter, $25 \mathrm{~cm}$ in height) filled with silt loam soil (USDA system) (fine, montmorillonitic, mesic, Aquic, Arquidoll, $\mathrm{pH}$ 7.3), which were collected from Lanzhou University research farm, Lanzhou, China. Nutrient analysis of the soil (at the beginning of the study) indicated the following nutrient levels: $3.4 \mathrm{~g} \cdot \mathrm{kg}^{-1}$ total nitrogen, $0.72 \mathrm{~g} \cdot \mathrm{kg}^{-1}$ phosphorus, $5.5 \mathrm{~g} \cdot \mathrm{kg}^{-1}$ organic matter, $0.353 \mathrm{~g} \cdot \mathrm{kg}^{-1}$ soluble sodium (Na), $0.359 \mathrm{~g} \cdot \mathrm{kg}^{-1}$ soluble potassium $(\mathrm{K})$, $0.159 \mathrm{~g} \cdot \mathrm{kg}^{-1}$ exchangeable and available nonexchangeable $\mathrm{Na}, 0.013 \mathrm{~g} \cdot \mathrm{kg}^{-1}$ exchangeable and available non-exchangeable $\mathrm{K}$, and $4.6 \mathrm{~g} \cdot \mathrm{kg}^{-1}$ salt.

The experiment was conducted in four growth chambers set at optimum temperature $\left(23 / 15{ }^{\circ} \mathrm{C}\right.$, day/night), photosynthetically active radiation of $500 \mu \mathrm{mol} \cdot \mathrm{m}^{-2} \cdot \mathrm{s}^{-1}$ with a photoperiod of $14 \mathrm{~h}$, and relative humidity of $70 \%$. Soil water content was maintained at $32.6 \%$ (50\% of saturated water content) from the date of planting time to the end of the experiment by weighing the PVC and adding tap water back with an electronic balance and to determine the effect of Si without other fertilizer amendment during the whole experimental period (Liu et al., 2009).

Treaments. The experiment consisted of six treatments including a control (no salinity and no $\mathrm{Si}$ amendment) and $\mathrm{Si}$ amendment at $0,0.24,0.48,0.72$, and $0.96 \mathrm{~g} \mathrm{Si} / \mathrm{kg}$ soil levels under salinity stress. Sodium silicate used as a Si source $\left(\mathrm{Na}_{2} \mathrm{SiO}_{3}\right.$; Tianjin Double Boat Chemical Co., Tianjin, China) is composed of $102 \mathrm{~g} \cdot \mathrm{kg}^{-1} \mathrm{Si}, 161.8 \mathrm{~g} \cdot \mathrm{kg}^{-1} \mathrm{Na}$, and other minor elements such as $\mathrm{SO}_{4}{ }^{2-}\left(1 \mathrm{~g} \cdot \mathrm{kg}^{-1}\right)$, $\mathrm{Cl}^{-}\left(1 \mathrm{~g} \cdot \mathrm{kg}^{-1}\right)$, and lead $\left(0.1 \mathrm{~g} \cdot \mathrm{kg}^{-1}\right)$. The sodium silicate was incorporated into each treated pot to obtain the rates of elemental Si. Sodium chloride was added to the pots treated with 0 , $0.24,0.48$, or $0.72 \mathrm{~g} \mathrm{Si} / \mathrm{kg}$ soil to equilibrate the amount of $\mathrm{Na}$ present in these treatments with the treatment containing $0.96 \mathrm{~g} \mathrm{Si} / \mathrm{kg}$ soil. Thus, the salt content was $10 \mathrm{~g} \cdot \mathrm{kg}^{-1}$ 
(calculated as $\mathrm{NaCl}$ ) in all treatments except the untreated control.

Growth analysis. The number of seedlings emerged from each pot was counted every $2 \mathrm{~d}$ and the numbers of plants were used to determine the rate of germination. Ten marked plants (randomly selected at earlier beginning of the experiment) from each pot were measured every $4 \mathrm{~d}$ for plant height. Plant height was measured from the ground to the top of each plant. Tiller number of each treatment was calculated after $50 \mathrm{~d}$ of treatment. Each replicate (pot) was photographed, and the resulting images were processed and analyzed to quantify the percent canopy coverage by using a WinCAM Color Analysis System (Regent Instruments Inc., 2004a, Quebec, Canada). Individual leaf area was calculated using WinFOLIA Scan System (Regent Instruments Inc., 2004a).

Physiological measurements. Cell membrane stability was estimated by measuring electrolyte leakage (EL) of leaves. Samples of $0.5 \mathrm{~g}$ of leaves were rinsed with deionized water, immersed in $25 \mathrm{~mL}$ of deionized water, and subjected to a vacuum of $48 \mathrm{kPa}$ for $15 \mathrm{~min}$. Leaves were shaken in flasks of deionized water on a shaker for $24 \mathrm{~h}$. The conductivity of the solution $\left(\mathrm{C}_{\text {initial }}\right)$ was measured using a conductivity meter (DDSJ 308A; Shanghai Cany Precision Instrument Co., Ltd., Shanghai, China). Leaves then were killed by autoclaving at $140{ }^{\circ} \mathrm{C}$ for $20 \mathrm{~min}$. The conductivity of killed tissues $\left(\mathrm{C}_{\max }\right)$ was measured. Relative percent EL was calculated as using the formula $\mathrm{C}_{\text {initial }} / \mathrm{C}_{\max } * 100$ (Liu and Huang, 2000).

Shoots and roots were sampled from each pot, washed at least three times in water, dried in an oven at $80^{\circ} \mathrm{C}$ for $3 \mathrm{~d}$, and then ground into powder to pass a $0.5-\mathrm{mm}$ sieve. Shoots and roots were extracted in $10 \mathrm{~mL}$ acetic acid $\left(5.7 \mathrm{~mL} \cdot \mathrm{L}^{-1}\right)$ for $2 \mathrm{~h}$ at $90{ }^{\circ} \mathrm{C}$. Sodium and $\mathrm{K}$ were determined in the extract by Cole-Palmer Digital Flame Analyzer, Model 2655-00 (Cole-Palmer Instrument, Chicago, IL) (Flowers et al., 2000).

The experimental design and statistical analysis. There were six treatments with four replications in a completely randomized block design. Each treatment was repeated in four growth chambers as four replications. The main effects of treatments were analyzed by standard analysis of variance procedures using the general linear model (GLM) procedure. Treatment means were separated using the least significant differences option of the GLM procedure test at $P=0.05$ (SAS Version 9; SAS Institute, Cary, NC).

\section{Results}

Germination and growth response. Seed germination rate was significantly reduced by $20 \%$ when plants were grown in $0 \mathrm{Si}$ under saline conditions compared with the control at $8 \mathrm{~d}$ of treatments (Fig. 1). Germination rate significantly $(P<0.05)$ increased after $12 \mathrm{~d}$ of $0.48 \mathrm{~g} \mathrm{Si}$ treatment compared with that in Si-untreated plants. The germination rate under $0.48 \mathrm{~g}$ Si was $28 \%$ higher than that of
$0 \mathrm{Si}$ under saline conditions after $20 \mathrm{~d}$ of treatments. However, application of $\mathrm{Si}$ at other rates $(0.24,0.72,0.96 \mathrm{~g})$ did not affect the germination when compared with $0 \mathrm{Si}$ under saline conditions.

Plant height was greatly reduced in $0 \mathrm{Si}$ under saline conditions compared with the controls after $36 \mathrm{~d}$ of treatments (Fig. 2). Supplying $0.72 \mathrm{~g} \mathrm{Si} / \mathrm{kg}$ treatment significantly $(P<0.05)$ increased plant height after $40 \mathrm{~d}$ compared with $0 \mathrm{Si}$ under saline conditions. Plant height was $7 \%, 13 \%, 34 \%$, and $32 \%$ higher than that of $0 \mathrm{Si}$ under saline conditions for $0.24,0.48,0.72$, and $0.96 \mathrm{~g} \mathrm{Si}$ treatments, respectively, after $52 \mathrm{~d}$.

Canopy coverage of control plants was significantly increased by $11.7 \%$ than plants in $0 \mathrm{Si}$ under saline conditions after $20 \mathrm{~d}$ (Fig. $3)$. There was no significant difference in canopy coverage among all the $\mathrm{Si}$ amendment treatments on $32 \mathrm{~d}$ of treatment. Coverage was significantly $(P<0.05)$ increased by the use of Si on $44 \mathrm{~d}$. The canopy coverage was $61 \%, 82 \%$, and $78 \%$ higher for 0.48 ,
0.72 , and $0.96 \mathrm{~g} \mathrm{Si}$ treatments, respectively, compared with $0 \mathrm{Si}$ under saline conditions.

Leaf area and leaf blade length were significantly decreased by $\cdot 35 \%$ and $25 \%$, respectively, in $0 \mathrm{Si}$ under saline conditions compared with the control after $60 \mathrm{~d}$ of treatment (Figs. 4 and 5), but no significant differences were detected in maximum leaf width. Supplying plants with $0.48,0.72$, and $0.96 \mathrm{~g}$ Si significantly $(P<0.05)$ increased leaf area compared with $0 \mathrm{Si}$ under saline conditions. Leaf area was $33 \%, 35 \%$, and $33 \%$ higher than $0 \mathrm{Si}$ under saline conditions for $0.48,0.72$, and $0.96 \mathrm{~g} \mathrm{Si}$ treatments, respectively.

Tiller number was significantly decreased $\approx 85 \%$ in $0 \mathrm{Si}$ under saline conditions compared with the control after $50 \mathrm{~d}$ of treatment (Fig. 6). Tillers per plant under $0.96 \mathrm{~g} \mathrm{Si}$ was 6.3 times higher than $0 \mathrm{Si}$ under saline conditions. Average tillers per plant were both 3.7 times higher than in $0 \mathrm{Si}$ under saline conditions with $\mathrm{Si}$ rates of 0.48 and $0.72 \mathrm{~g} \mathrm{Si}$.

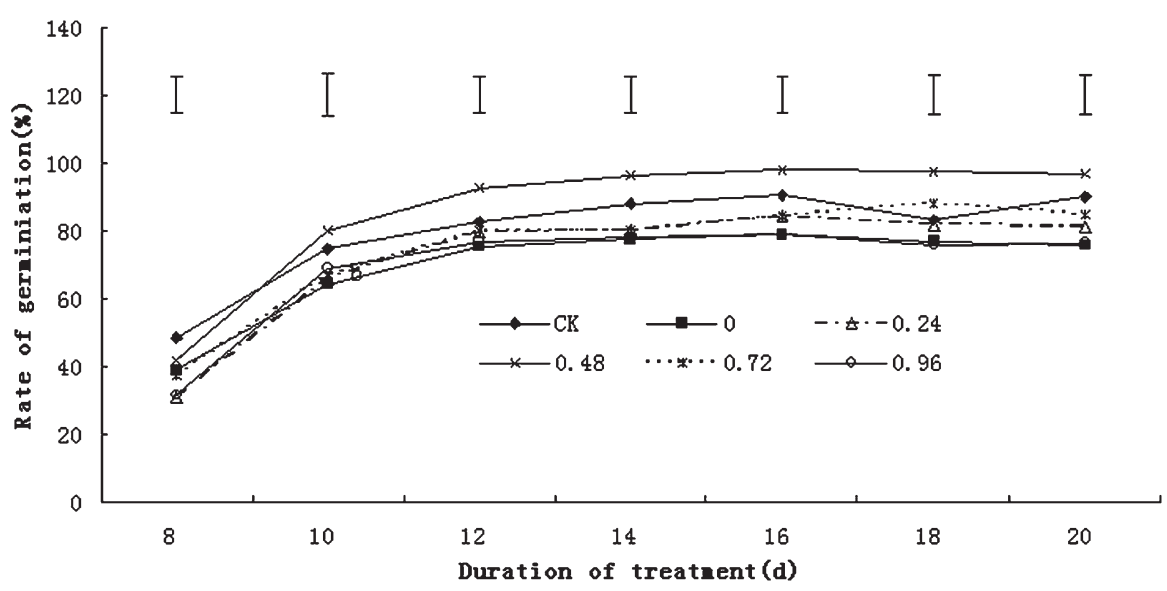

Fig. 1. Germination rate of 'Baron' kentucky bluegrass as affected by silicon ( $\mathrm{Si}$ ) amendment at $0,0.24$, $0.48,0.72$, and $0.96 \mathrm{~g} \cdot \mathrm{kg}^{-1}$ soil levels under salinity stress and control. Vertical bars on the top indicate least significant difference values $(P \leq 0.05)$ for treatments comparison at the given day of treatment.

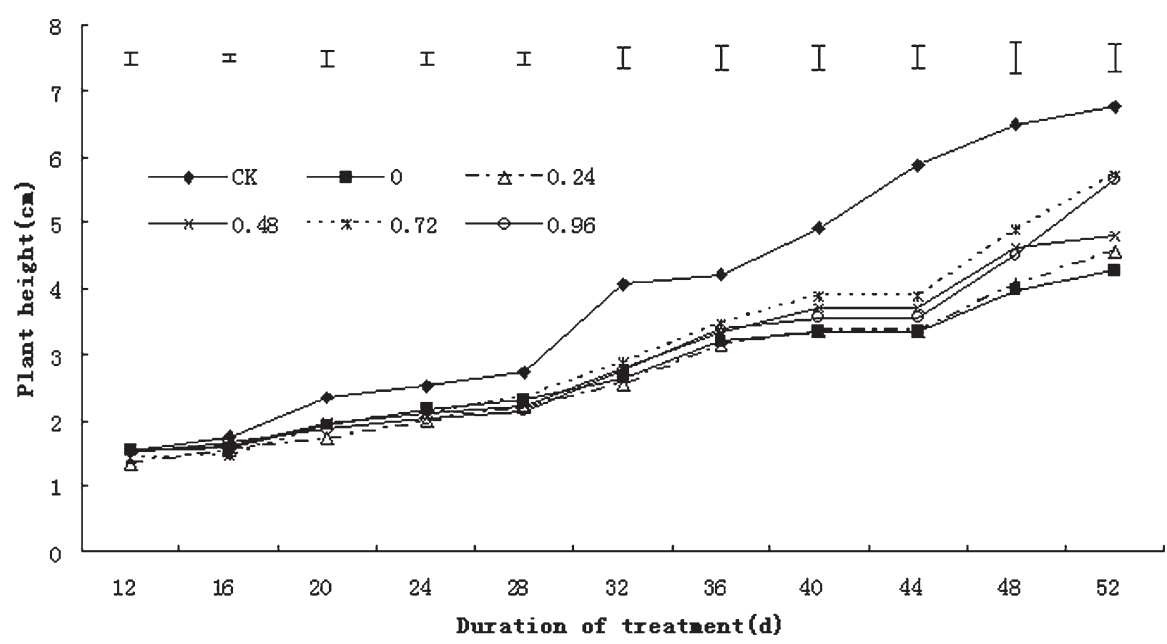

Fig. 2. Plant height of 'Baron' kentucky bluegrass as affected by silicon ( $\mathrm{Si}$ ) amendment at $0,0.24,0.48$, 0.72 , and $0.96 \mathrm{~g} \cdot \mathrm{kg}^{-1}$ soil levels under salinity stress and control. Vertical bars on the top indicate least significant difference values $(P \leq 0.05)$ for treatments comparison at the given day of treatment. 


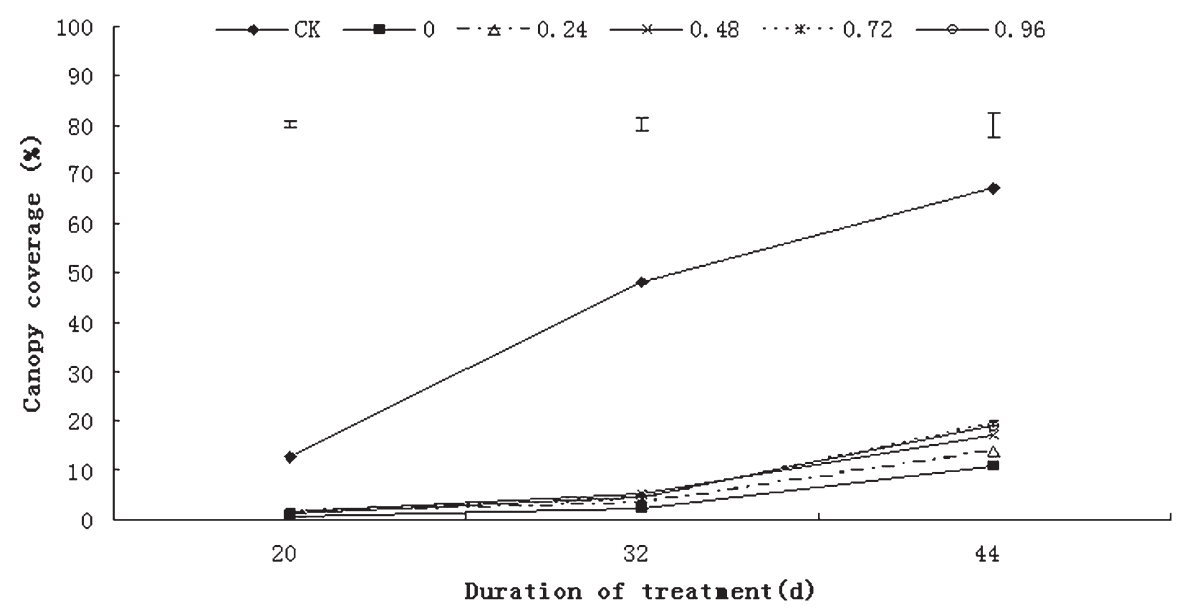

Fig. 3. Canopy coverage of 'Baron' kentucky bluegrass as affected by silicon ( $\mathrm{Si}$ ) amendment at $0,0.24$, $0.48,0.72$, and $0.96 \mathrm{~g} \cdot \mathrm{kg}^{-1}$ soil levels under salinity stress and control. Vertical bars on the top indicate least significant difference values $(P \leq 0.05)$ for treatments comparison at the given day of treatment.

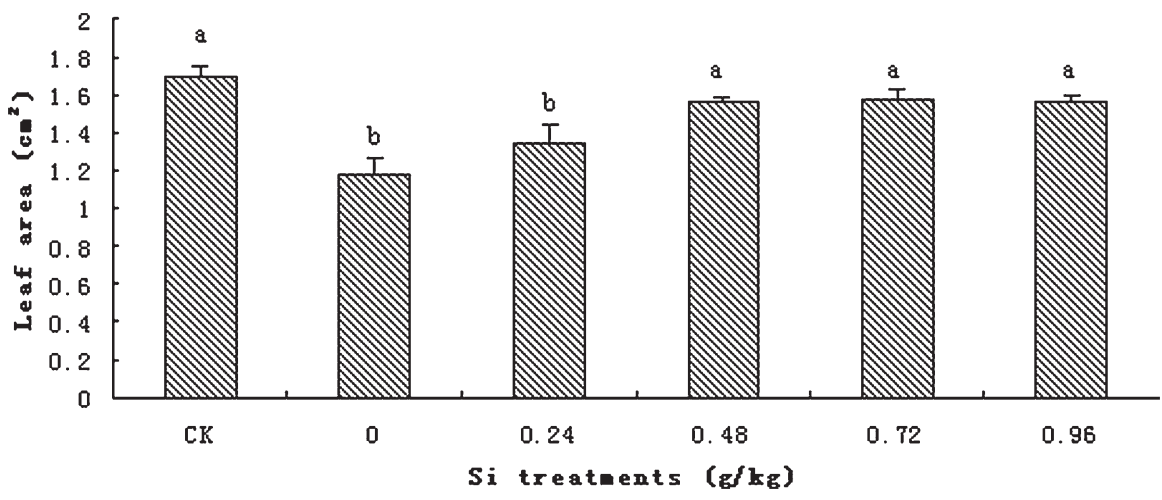

Fig. 4. Leaf area of 'Baron' kentucky bluegrass as affected by silicon ( $\mathrm{Si}$ ) amendment at 0, 0.24, 0.48, 0.72, and $0.96 \mathrm{~g} \cdot \mathrm{kg}^{-1}$ soil levels under salinity stress and control after $60 \mathrm{~d}$ of treatments. Treatments with same lowercase are not significantly different at $P \leq 0.05$.

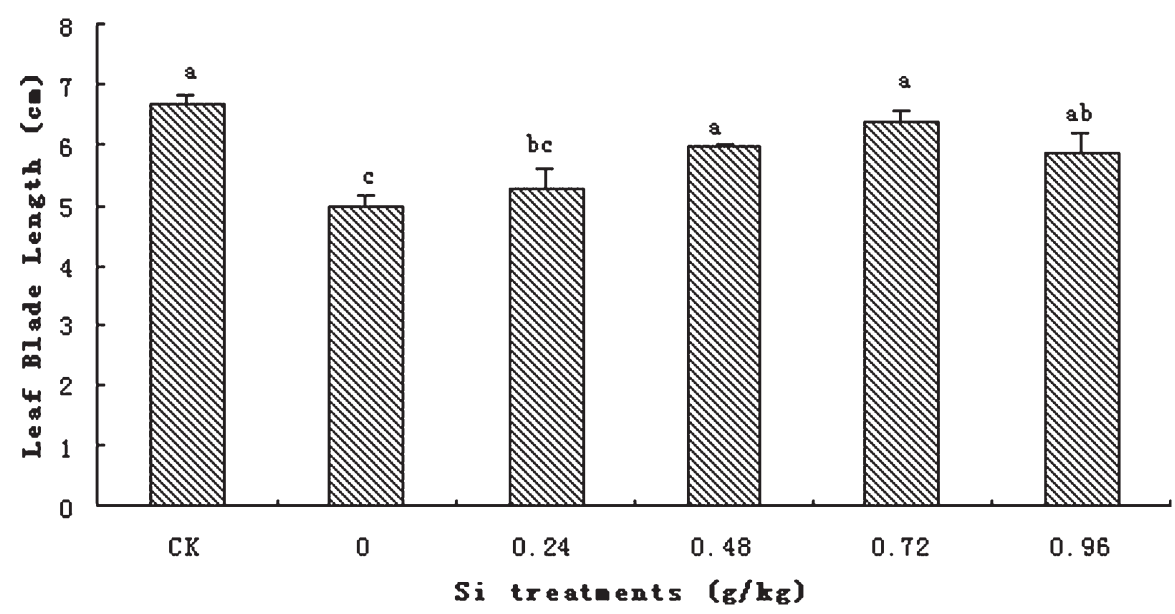

Fig. 5. Leaf blade length of 'Baron' kentucky bluegrass as affected by silicon ( $\mathrm{Si}$ ) amendment at $0,0.24$, $0.48,0.72$, and $0.96 \mathrm{~g} \cdot \mathrm{kg}^{-1}$ soil levels under salinity stress and control after $60 \mathrm{~d}$ of treatments. Treatments with same lowercase are not significantly different at $P \leq 0.05$.

Electrolyte leakage. EL of leaves was $\approx 33 \%$ higher in $0 \mathrm{Si}$ under saline conditions compared with that of the control after $60 \mathrm{~d}$ of treatment (Fig. 7). EL was significantly $(P<0.05)$ reduced by the use of Si under 0.48 and $0.72 \mathrm{~g} \mathrm{Si}$ amendment treatments compared with that of $0 \mathrm{Si}$ under saline conditions. After $60 \mathrm{~d}$ of treatment, EL was $40 \%$, $57 \%, 60 \%$, and $43 \%$ lower than that of $0 \mathrm{Si}$ under saline conditions for plants receiving rates of $0.24,0.48,0.72$, and $0.96 \mathrm{~g} \mathrm{Si}$, respectively.

Distribution of $\mathrm{Na}^{+}$and $\mathrm{K}^{+}$. Concentrations of $\mathrm{K}^{+}$were higher in shoots than in roots in all treatments after $60 \mathrm{~d}$ of treatments (Fig. 8 ). The concentrations were $\approx 36 \%$ and $22 \%$ lower in shoots and in roots, respectively, in $0 \mathrm{Si}$ under saline conditions relative to the controls. There was an increase in shoot $\mathrm{K}^{+}$ concentrations with the use of $\mathrm{Si}$, but it had no significant changes in roots in all the $\mathrm{Si}$ amendment treatments.

The concentrations of $\mathrm{Na}^{+}$were 7.78 and 4.51 times higher in shoots and in roots, respectively, under $0 \mathrm{Si}$ under saline conditions than the control after $60 \mathrm{~d}$ treatment (Fig. 9). With Si application, the concentrations of $\mathrm{Na}^{+}$decreased compared with $0 \mathrm{Si}$ under saline conditions. The content of $\mathrm{Na}^{+}$ was $13 \%, 38 \%, 48 \%$, and $40 \%$ lower in shoots than that of $0 \mathrm{Si}$ under saline conditions for $0.24,0.48,0.72$, and $0.96 \mathrm{~g} \mathrm{Si}$ amendment treatments, respectively, and that was $24 \%, 27 \%, 36 \%$, and $28 \%$ lower in roots, respectively.

$\mathrm{Na}^{+} / \mathrm{K}^{+}$ratios were 11.11 and 8.80 times higher in shoots and in roots, respectively, under $0 \mathrm{Si}$ under saline conditions than the control after $60 \mathrm{~d}$ of treatments (Fig. 10). $\mathrm{Na}^{+} /$ $\mathrm{K}^{+}$ratio also decreased with the addition of $\mathrm{Si}$ but changed more in shoots than in roots in all $\mathrm{Si}$ amendment treatments. The ratio in roots was higher than in shoots of each salinity treatment.

\section{Discussion}

Crops grown in salt-affected soil may lead to reduction in growth and productivity (Netondo et al., 2004). High salt concentrations in soils account for large decreases in yields of a wide variety of crops all over the world (Tester and Davenport, 2003). Compared with other cool-season turfgrass species, KBG exhibited less salt tolerance than perennial ryegrass (Lolium perenne L.) and creeping bentgrass (Agrostis stolonifera L.) (Jing et al., 2009). Previous studies have shown that KBG plants were killed after 10to 15 - $\mathrm{d}$ exposure to $1.5 \% \mathrm{NaCl}$ treatment (Fei et al., 2005). Turfgrass germination is greatly retarded and seedling survival is difficult under saline conditions (Daniel and Freeborg, 1987). In this study, germination rate decreased in saline soils and plants exhibited $12 \%$ to $35 \%$ reduction in canopy coverage, tiller number, and plant height relative to the control.

Silicon has been regarded as a beneficial element in a number of species of the Poaceae and Cyperaceae (Jin, 2001). The Si content in dry matter of Poa alpine L., Poa chaixi Will., and Poa secunda J. S. Presl. were $0.61,0.7$ to 0.9 , and $2.63 \%$, respectively (Carnelli et al., 2001). Application of Si as sodium metasilicate doubled plant Si concentration and increased grain yield in rice (Winslow, 1992). In experiments with rice and wheat, addition of silicate to the growing solution enhanced the resistance of the plants to salinity stress (Epstein, 1994). The application of Si promoted 


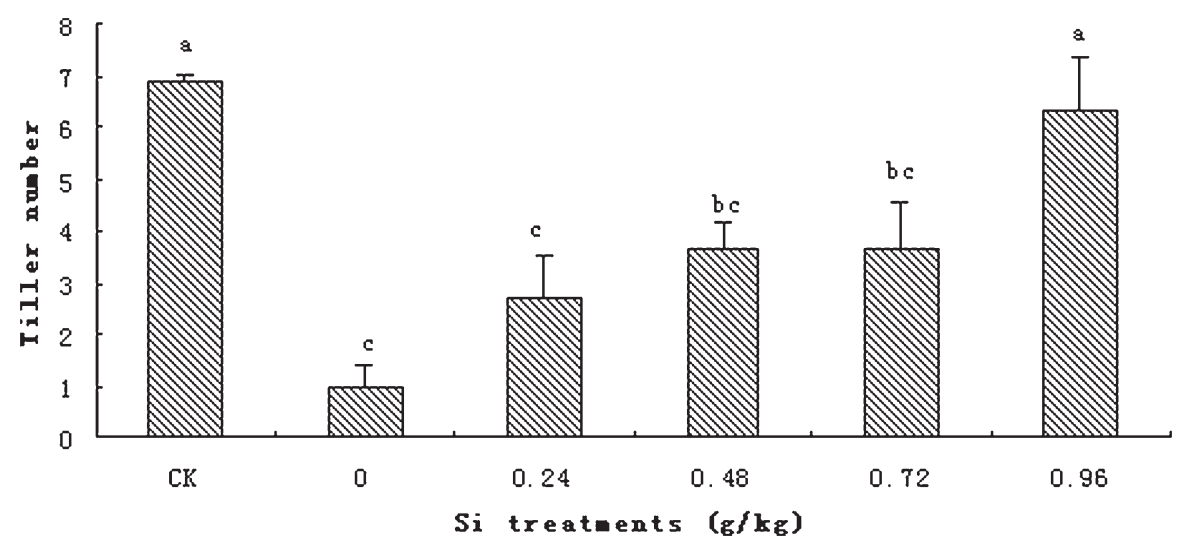

Fig. 6. Tiller number of 'Baron' kentucky bluegrass as affected by silicon ( $\mathrm{Si}$ ) amendment at $0,0.24,0.48$, 0.72 , and $0.96 \mathrm{~g} \cdot \mathrm{kg}^{-1}$ soil levels under salinity stress and control after $50 \mathrm{~d}$ of treatment. Treatments with same lowercase are not significantly different at $P \leq 0.05$.

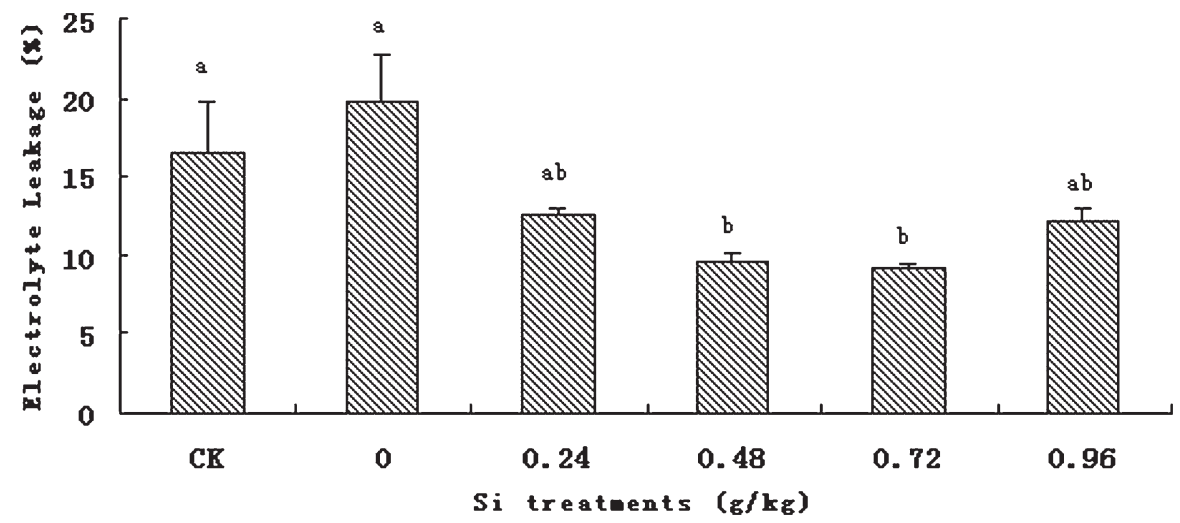

Fig. 7. Electrolyte leakage (\%) of 'Baron' kentucky bluegrass as affected by silicon ( $\mathrm{Si}$ ) amendment at 0 , $0.24,0.48,0.72$, and $0.96 \mathrm{~g} \cdot \mathrm{kg}^{-1}$ soil levels under salinity stress and control after $60 \mathrm{~d}$ of treatment Treatments with same lowercase are not significantly different at $P \leq 0.05$.

EShoot

\& Root

豆

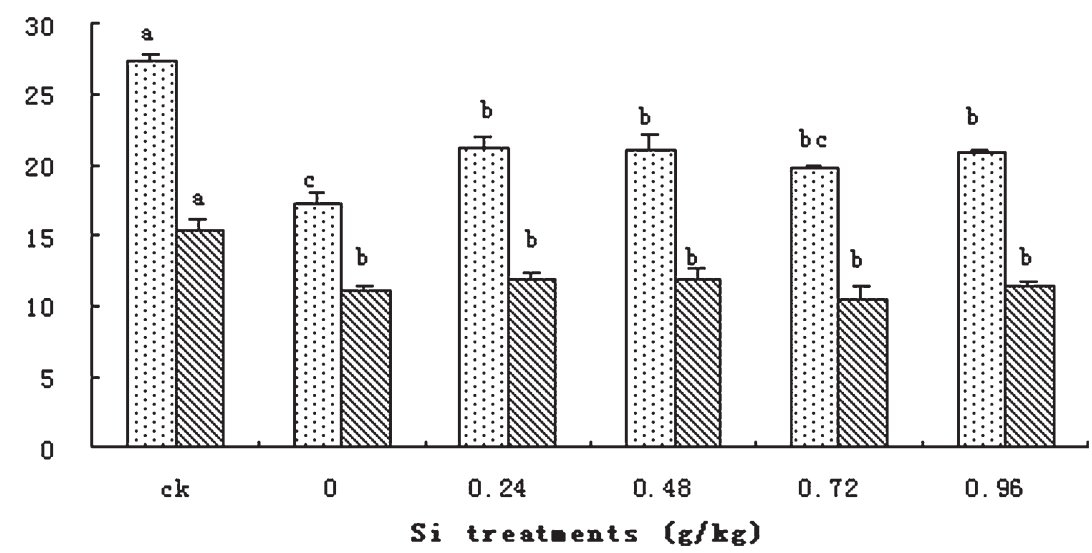

Fig. 8. $\mathrm{K}^{+}$concentration of 'Baron' kentucky bluegrass as affected by silicon ( $\mathrm{Si}$ ) amendment at $0,0.24$, $0.48,0.72$, and $0.96 \mathrm{~g} \cdot \mathrm{kg}^{-1}$ soil levels under salinity stress and control after $60 \mathrm{~d}$ of treatment Treatments with same lowercase in shoots or in roots are not significantly different at $P \leq 0.05$.

germination rate and leaf growth of KBG in saline soils and this is in agreement with the results by Li and Ma (2003). In our experiment, the maximum germination rates of the $\mathrm{Si}$ amendment treatments were more than
$20 \%$ higher than that under $0 \mathrm{Si}$ under saline conditions. Canopy coverage of the Si amendment plants was nearly twice that of $0 \mathrm{Si}$ under saline conditions and the tiller number in $\mathrm{Si}$ amendment plants was more than six times of $0 \mathrm{Si}$ under saline conditions. Similar positive effects of Si have been found on the growth of cucumber plants (Epstein, 1994). The present study also indicated that $\mathrm{Si}$ application was able to maintain a lower EL under Si amendment treatment than $0 \mathrm{Si}$ under saline conditions, suggesting that Si may alleviate cellular membrane damage caused by salinity stress of KBG. This may be a result of $\mathrm{Si}$ supplement to the absorption of $\mathrm{K}^{+}$and $\mathrm{Na}^{+}$from the soil and transportation in the plant from roots to shoots.

Although $\mathrm{K}^{+}$is a major macronutrient (Wang et al., 2004), the accumulation of $\mathrm{K}^{+}$ in the roots and leaves is strongly inhibited by salinity (Netondo et al., 2004). In this study, salinity caused $\mathrm{K}^{+}$reduction by $36 \%$ in shoots and $22 \%$ in roots. Too great of a reduction in the concentration of $\mathrm{K}^{+}$in leaves under salinity could cause a specific ion deficiency that reduces plant growth (Netondo et al., 2004).

For many plants (such as graminaceous crops), $\mathrm{Na}^{+}$is the primary cause of ionspecific damage (Tester and Davenport, 2003). In this study, salinity caused 7.78 and 4.51 times the $\mathrm{Na}^{+}$concentration rise both in shoots and in roots compared with controls. High concentrations of $\mathrm{Na}^{+}$may have disturbed intracellular ion homeostasis, which led to membrane dysfunction, attenuation of metabolic activity, and secondary effects that cause growth inhibition and ultimately lead to cell death (Wang et al., 2004). The application of $0.72 \mathrm{~g}$ Si inhibited $48 \% \mathrm{Na}^{+}$in shoots and $36 \%$ in roots compared with $0 \mathrm{Si}$ under saline conditions. In experiments with rice and wheat, addition of silicate to the solution cultures also reduced the $\mathrm{Na}^{+}$concentration in the plants (Epstein, 1994). Slowly absorbed $\mathrm{Na}^{+}$can reduce toxicity of $\mathrm{Na}^{+}$accumulation (Yin et al., 1997).

Salinity stress, especially $\mathrm{NaCl}$ stress, reduced $\mathrm{K}^{+}$content and $\mathrm{K}^{+} / \mathrm{Na}^{+}$ratios in shoots and roots but increased $\mathrm{Na}^{+}$content and enhanced the selectivity of $\mathrm{K}^{+} / \mathrm{Na}^{+}$. The increments of $\mathrm{Na}^{+}$contents in shoot were higher than in the roots. $\mathrm{NaCl}$ stress duration affected the $\mathrm{K}^{+}$and $\mathrm{Na}^{+}$contents significantly and reduced the transportation selectivity ratios of $\mathrm{K}^{+}$and $\mathrm{Na}^{+}$, but $\mathrm{NaCl}$ concentration mainly influenced the absorption ratios of $\mathrm{K}^{+}$and $\mathrm{Na}^{+}$(Flowers, 2004). A previous study showed that with the increasing of $\mathrm{NaCl}$ concentration, $\mathrm{Na}^{+}$content increased, whereas $\mathrm{K}^{+}$ content and ratios of wheat $\mathrm{K}^{+} / \mathrm{Na}^{+}$declined (Xu et al., 2002). Under salinity stress, a representative index for balanced ions is the decrease of $\mathrm{K}^{+} / \mathrm{Na}^{+}$ratio (Li et al., 2005; Rasan et al., 2000). The larger the $\mathrm{K}^{+} / \mathrm{Na}^{+}$ ratio, the stronger ability for the root to inhibit $\mathrm{Na}^{+}$and promote transportation of $\mathrm{K}^{+}$ to shoots, indicating a stronger selective transport capacity of the root system (Wang, 1996; Wang et al., 1996, 2004). The salt tolerance in grasses is liable to have some certain selectivity to absorb $\mathrm{K}^{+}$and the salt tolerance in various grasses can be identified in various species through comparing the $\mathrm{K}^{+}$/ $\mathrm{Na}^{+}$ratio of leaf lamina when they are grown on soils that have the same salt contents 
B Shoot

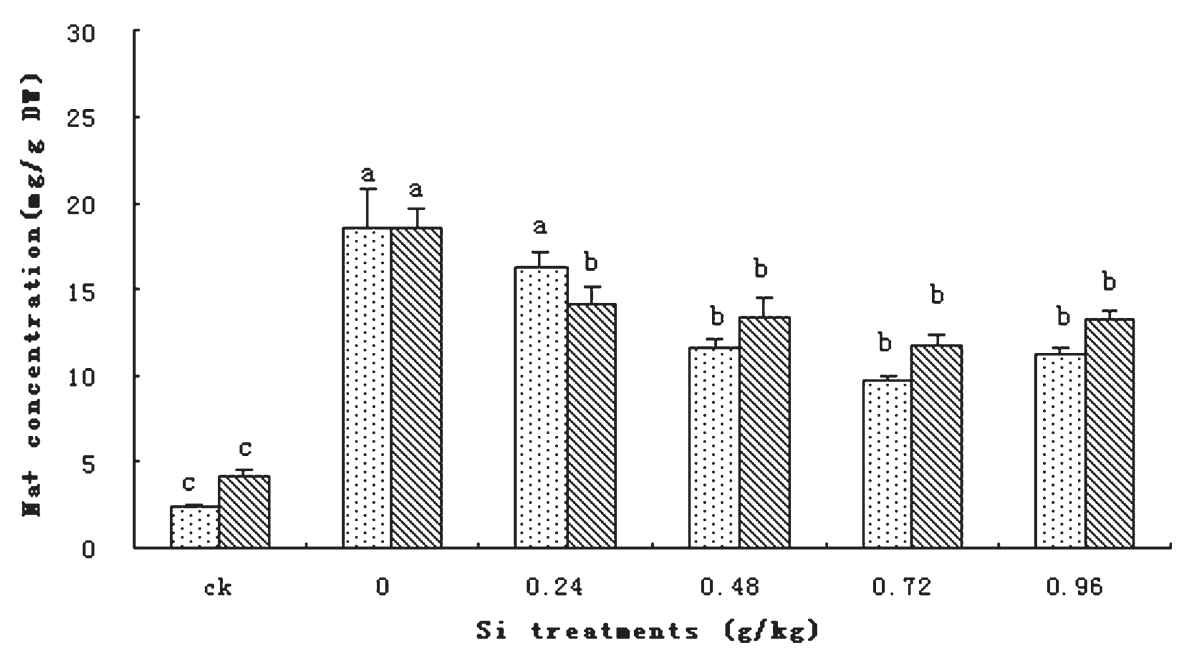

Fig. 9. $\mathrm{Na}^{+}$concentration of 'Baron' kentucky bluegrass as affected by silicon ( $\mathrm{Si}$ ) amendment at $0,0.24$, $0.48,0.72$, and $0.96 \mathrm{~g} \cdot \mathrm{kg}^{-1}$ soil levels under salinity stress and control after $60 \mathrm{~d}$ of treatment. Treatments with same lowercase in shoots or in roots are not significantly different at $P \leq 0.05$.

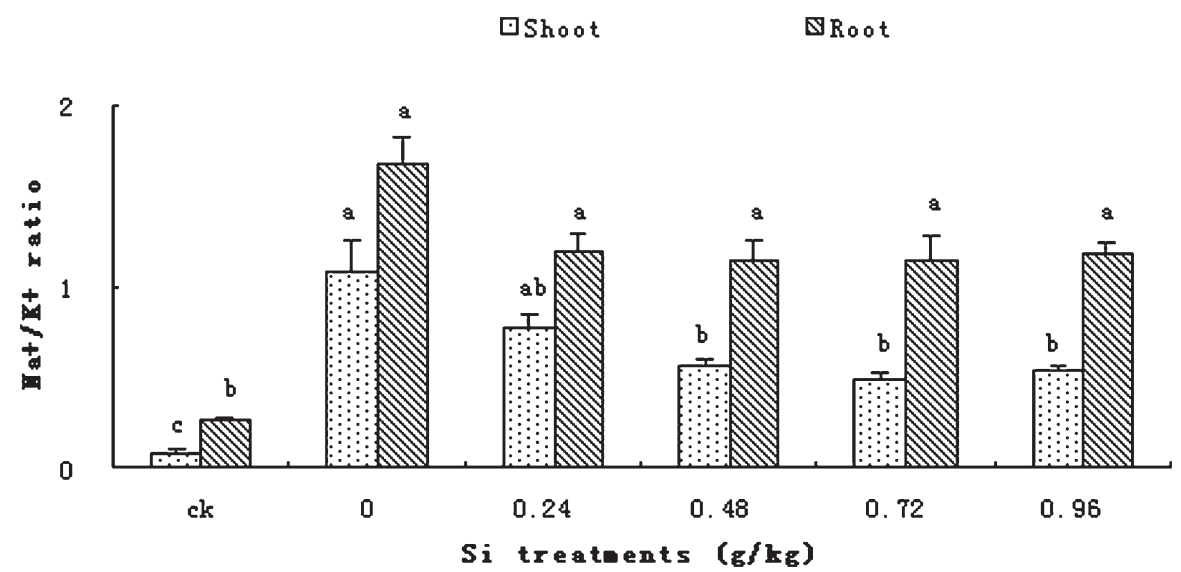

Fig. 10. $\mathrm{Na}^{+} / \mathrm{K}^{+}$ratio of 'Baron' kentucky bluegrass as affected by silicon ( $\mathrm{Si}$ ) amendment at $0,0.24,0.48$, 0.72 , and $0.96 \mathrm{~g} \cdot \mathrm{kg}^{-1}$ soil levels under salinity stress and control after $60 \mathrm{~d}$ of treatment. Treatments with same lowercase in shoots or in roots are not significantly different at $P \leq 0.05$.

(Wang et al., 2002). Grasses having higher $\mathrm{K}^{+} / \mathrm{Na}^{+}$rate were evaluated to possess also much greater variability in salt tolerance (Weng et al., 1998). High levels of $\mathrm{Na}^{+}$, or high $\mathrm{Na}^{+} / \mathrm{K}^{+}$ratios, can disrupt various enzymatic processes in the cytoplasm. Other nutrient deficiencies can occur because elevated $\mathrm{Na}^{+}$inhibits the uptake of other nutrients directly by interfering with transporters in the root plasma membrane such as $\mathrm{K}^{+}$selective ion channels (Tester and Davenport, 2003).

In summary, germination rate and growth of KBG decreased in saline soils. The application of $\mathrm{Si}$ increased seed germination and promoted shoot growth under saline conditions. Under salinity conditions, application of $\mathrm{Si}$ induced the transfer of $\mathrm{K}^{+}$from roots to shoots but inhibited the absorption and transfer of $\mathrm{Na}^{+}$, which may lead to less damage from salinity to the plants and result in higher turf quality.
Daniel, W.H. and R.P. Freeborg. 1987. Turf managers' handbook. Business Publications Division of Harvest Publishing Company, Cleveland, $\mathrm{OH}$, a division of Harcourt Brace Jovanovich, New York, NY.

Epstein, E. 1994. The anomaly of silicon in plant biology. Proc. Natl. Acad. Sci. USA 91:1117.

Epstein, E. 1999. Silicon. Annu. Rev. Plant Physiol. Plant Mol. Biol. 50:641-664.

Erusha, K.S., R.C. Shearman, T.P. Riordan, and L.A. Wit. 2002. Kentucky bluegrass cultivar root and top growth responses when grown in hydroponics. Crop Sci. 42:848-852.

Fei, Y.J., Y. Wang, Q.J. Li, F. Xiao, and J. Deng. 2005. Assessment on salt tolerance of several grass cultivars. Sichuan Cao Yuan. 5:20-24.

Flowers, T.J. 2004. Improving crop salt tolerance. J. Expt. Bot. 55:307-319.

Flowers, T.J., M.L. Koyama, S.A. Flowers, C. Sudhakar, K.P. Singh, and A.R. Yeo. 2000. QTL: Their place in engineering tolerance of rice to salinity. J. Expt. Bot. 51:99-106.

Jin, W.M. 2001. Soil fertilizer. China Agricuture Press, Beijing, China.

Jing, D., R.H. David, and J.S. Maxim. 2009. Salinity effects on seed germination and vegetative growth of greens-type Poa annua relative to other cool-season turfgrass species. Crop Sci. 49:696-703.

Kraska, J.E. and G.A. Breitenbeck. 2010. Survey the silicon status of flooded rice in Louisiana. Agron. J. 102:523-529.

Li, P.F., W.B. Bai, and Z.C. Yang. 2005. Effects of $\mathrm{NaCl}$ stress on ions absorption and transportation and plant growth of tall fescue. Scientia Agricultura Sinica. 38:1458-1465.

Li, Q. and C. Ma. 2003. Effect of available silicon in soil on nutritive metabolism of cotton seedling. Scientia Agricultura Sinica. 36:726730.

Liang, Y., R. Ding, and Q. Liu. 1999. Effect of silicon on salt tolerance of barley and its mechanism. Scientia Agricultura Sinica. 32:75-83.

Liang, Y.C. 1999. Effect of silicon on enzyme activity and sodium, potassium and calcium concentration in barley under salt stress. Plant Soil 209:217-224.

Liu, H., Z. Guo, X. Guo, X. Zhou, W. Hui, and K. Wang. 2009. Effect of addition of silicon on water use efficiency and yield components of alfalfa under the different soil moisture. Acta Ecol. Sin. 29:3075-3080.

Liu, X.Z. and B.R. Huang. 2000. Heat stress injury in relation to membrane lipid peroxidation in creeping bentgrass. Crop Sci. 40: 503-510

Ahmad, R., S.H. Zaheer, and S. Ismail. 1992. Role of silicon in salt tolerance of wheat (Triticum aestivum L.). Plant Sci. 85:43-50.

Beard, J.B. 1973. Turfgrass science and culture. Prentice Hall, Englewood Cliffs, NJ.

Carnelli, A.L., M. Madella, and J.P. Theurillat. 2001. Biogenic silica production in selected Alpine plant species and plant communities. Ann. Bot. (Lond.) 87:425-434.

Chinnusamy, V., A. Jagendorf, and J.-K. Zhu. 2005. Understanding and improving salt tolerance in plants. Crop Sci. 45:437-448.

Crusciol, C.A.C., A.L. Pulz, L.B. Lemos, R.P. Soratto, and G.P.P. Lima. 2009. Effects of silicon and drought stress on tuber yield and leaf biochemical characteristics in potato. Crop Sci. 49:949-954.

Dai, W.-M., K.-Q. Zhang, B.-W. Duan, K.-L. Zheng, J.-Y. Zhuang, and R. Ca. 2005. Genetic dissection of silicon content in different organs of rice. Crop Sci. 45:13451352.
Matoh, T., N. Matsushita, and E. Takahashi. 1988. Salt tolerance of the reed plant Phragmites communis. Physiol. Plant. 72:8-14.

Munns, R. 1993. Physiological processes limiting plant growth in saline soil. Some dogmas and hypotheses. Plant Cell Environ. 16:15-24.

Munns, R. 2002. Comparative physiology of salt and water stress. Plant Cell Environ. 25:239250.

Netondo, G.W., J.C. Onyango, and E. Beck. 2004 Sorghum and salinity: I. Response of growth, water relations, and ion accmulation to $\mathrm{NaCl}$ salinity. Crop Sci. 44:797-805.

Qian, Y.L., S.J. Wilhelm, and K.B. Marcum. 2001. Comparative responses of two kentucky bluegrass cultivars to salinity stress. Crop Sci. 41: 1895-1900.

Rasan, T., M. David, H. Yair, and T. Noshe. 2000. The relation between low $\mathrm{K} / \mathrm{Na}$ ratio and salttolerance in the wild tomato species Lycoperstcon penellii. J. Plant Physiol. 157:59-64. 
Shu, L. and Y. Liu. 2001. Effect of silicon on growth of maize seedlings under salt stress. Agro-environmental Protection. 20:38-40.

Tester, M. and R. Davenport. 2003. $\mathrm{Na}^{+}$tolerance and $\mathrm{Na}^{+}$transport in higher plants. Ann. Bot. (Lond.) 91:503-527.

Wang, C.Y., Y.X. Ma, S.M. Zhou, J.Z. Zhou, and Z.H. Si. 1996. Study on effects of soil drought stress on winter wheat senescence. Acta Agriculturae Universitatis Henanensis. 30:309-313.

Wang, S.M. 1996. Effect of salt stress on the characteristics of ion absorption and distribution in Puccinellia tenuiflora. Acta Agrestia Sinca. 4:186-193.

Wang, S.M., C.G. Wan, Y.R. Wang, H. Chen, Z.Y. Zhou, H. Fu, and R.E. Sosebee. 2004. The characteristics of $\mathrm{Na}^{+}, \mathrm{K}^{+}$and free proline distribution in several drought-resistant plants of the Alxa Desert, China. J. Arid Environ. 56: 525-539.

Wang, S.M., W.J. Zheng, J.Z. Ren, and C.L. Zhang. 2002. Selectivity of various types of saltresistant plants for $\mathrm{K}^{+}$over $\mathrm{Na}^{+}$. J. Arid Environ. 52:457-472.

Weng, S.H., S.M. Nie, H.G. Xu, and A.L. Gu. 1998. The interrelation of $\mathrm{K}^{+} / \mathrm{Na}^{+}$content with salt tolerance of grass species in the gramineae family. Sichuan Cao Yuan. 2:22-30.

Winslow, M. 1992. Silicon, disease resistance, and yield of rice genotypes under upland cultural conditions. Crop Sci. 32:1208-1213.

Xu, X., S.H. Li, H.X. Hui, and H.L. Mi. 2002. Effect of $\mathrm{NaCl}$ stress on growth, chlorophyll content and $\mathrm{K}^{+} / \mathrm{Na}^{+}$absorption of spring wheat seedlings. Acta Botanica Boreali-Occidentalia Sinica. 22:278-284.

Yeo, A.R., S.A. Flowers, G. Rao, K. Welfare, N. Senanayake, and T.J. Flowers. 1999. Silicon reduces sodium uptake in rice (Oryza sativa L.) in saline conditions and this accounted for by a reduction in the transpirational bypass flow. Plant Cell Environ. 22:559-565.

Yin, K.D., G.L. Li, H.X. Li, Y.G. Li, and Z.C. Tang. 1997. Changes of $\mathrm{K}^{+} \mathrm{Na}^{+}$content and absorbing $\mathrm{Na}^{+}$rate in salt-adapted tobacco callus. J. Heilongjiang August Firet Land Reclamation University. 9:7-9.

Zhang, Y., Z. Li, M. Li, and X. Du. 2004. The study of complex alkali-saline stress on four varieties of Poa pratensis. Chinese Agricultural Science Bulletin. 20:209-213. 